\title{
Assessing the hydrological impacts of coal resource development: a case study from Australia
}

\author{
D. A. Post \\ Commonwealth Scientific and Industrial Research Organization, CSIRO Land and Water, \\ GPO Box 1700, ACT, Canberra, 2601, Australia
}

For citation: Post, D. A. (2021). Assessing the hydrological impacts of coal resource development: a case study from Australia. Vestnik of Saint Petersburg University. Earth Sciences, 66 (1), 91-106. https://doi.org/10.21638/spbu07.2021.106

The objective of this study is to predict regional-scale cumulative impacts on water resources caused by coal resource developments in the Gloucester subregion of New South Wales (NSW), Australia. A key outcome of the assessment is identifying areas where water resources are very unlikely to be impacted (with a less than $5 \%$ chance) from those where water resources are potentially impacted (at least a $5 \%$ chance). Governments, industry and the community can then focus on areas that are potentially impacted when making regulatory, water management and planning decisions. Potential impacts were ruled out using a zone of potential hydrological change. This zone was defined based on at least a $5 \%$ chance of exceeding defined thresholds in multiple hydrological response variables including groundwater drawdown and eight streamflow metrics (only reductions in annual streamflow are reported here). The zone of potential hydrological change in the Gloucester subregion covers $250 \mathrm{~km}^{2}$ and includes $242 \mathrm{~km}$ of stream network. This represents $52 \%$ of the area and $70 \%$ of the stream length assessed. Groundwater drawdown exceeding $0.2 \mathrm{~m}$ in the near surface aquifer due to additional coal resource development is very likely (>95\% chance) for an area of $20 \mathrm{~km}^{2}$ but is very unlikely ( $<5 \%$ chance) to exceed an area of $100 \mathrm{~km}^{2}$. Although $242 \mathrm{~km}$ of streams are identified as being potentially impacted, changes in streamflow are small, with a little over $5 \%$ reduction in annual flow in some streams close to the coal mines, and reductions in annual flow in the major rivers not exceeding $1-5 \%$.

Keywords: coal resource development, groundwater, surface water, Australia.

\section{Introduction}

The Gloucester subregion covers about $348 \mathrm{~km}^{2}$ and is defined by the geological Gloucester Basin. It is located just north of the Hunter Valley in NSW and is approximately $60 \mathrm{~km}$ south-west of Taree and $55 \mathrm{~km}$ west of Forster (Fig. 1). The subregion extends $55 \mathrm{~km}$ north-south (at its longest) and $15 \mathrm{~km}$ east-west (at its widest). Elevation in the subregion ranges from 10 to $515 \mathrm{~m}$ Australian Height Datum (AHD), and it is mostly undulating with relatively low slopes; some steeper slopes are found along the western and eastern flanks of the geological basin.

Current vegetation cover is mainly persistent vegetation associated with forests along the edge of the subregion and grazing (covering over $75 \%$ of the subregion). There are numerous rivers in the subregion that straddle a catchment divide; north-flowing rivers contribute to the Manning River and discharge to the Tasman Sea beyond Taree and

(C) St. Petersburg State University, 2021 


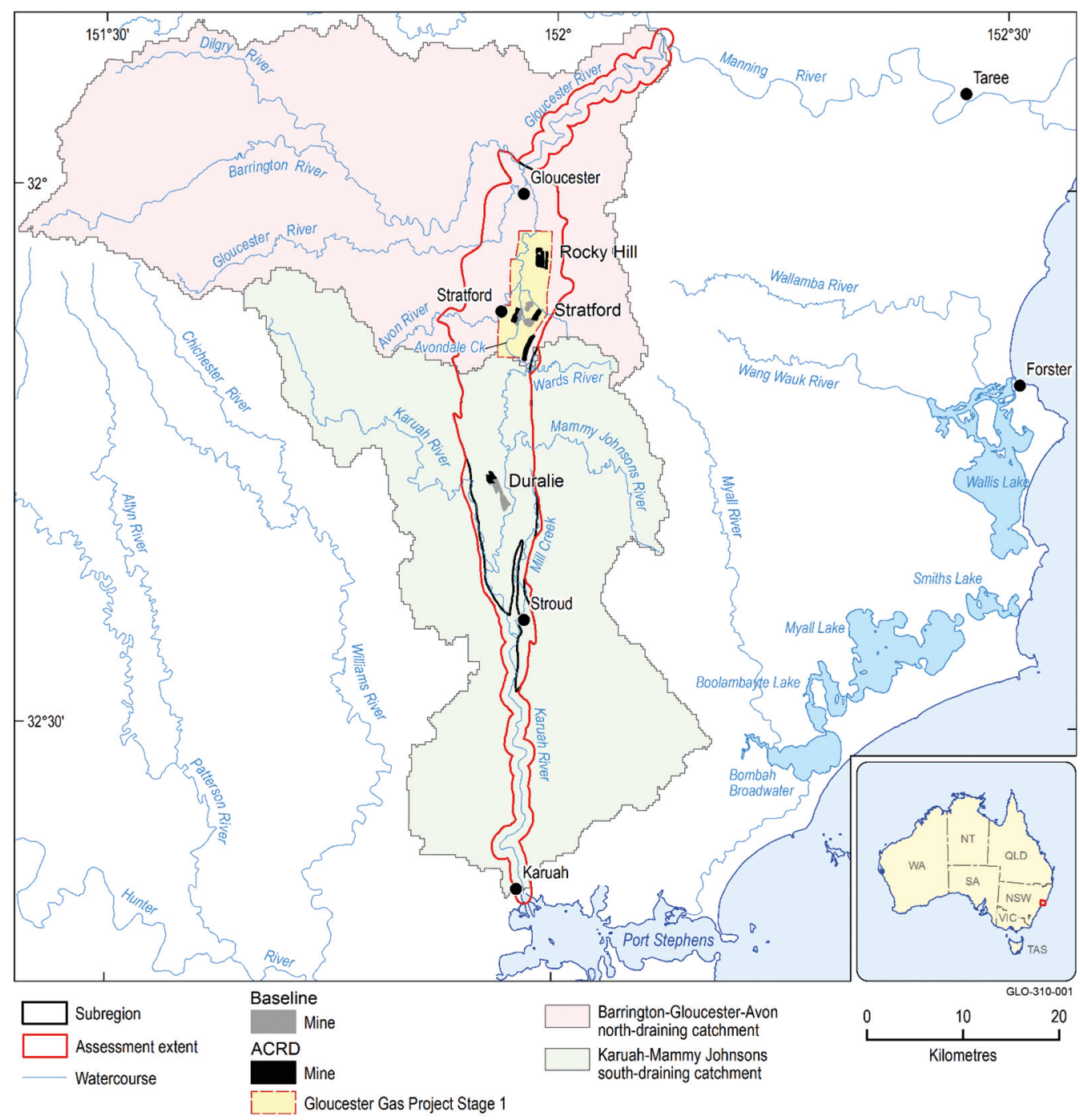

Fig. 1. Baseline and additional coal resource developments (ACRD) in the Gloucester subregion. Reproduced from Fig. 4 in (Post et al., 2018)

the south-flowing rivers contribute to the Karuah River and discharge into Port Stephens (Fig. 1). From a groundwater perspective, it is a closed system, with recharge and discharge confined to the syncline structure of the Gloucester geological basin.

The climate is sub-tropical, characterised by summer-dominant precipitation. Average precipitation over the last 30 years (1982 to 2012) was $1095 \mathrm{~mm}$ /year with potential evapotranspiration (PET) of $1587 \mathrm{~mm} /$ year.

This study is a regional analysis that compares two futures of coal resource development. The term 'coal resource development' specifically includes coal mining (both opencut and underground) as well as coal seam gas extraction. Other forms of coal-related development activity, such as underground coal gasification and microbial enhancement of gas resources, are not within the scope of this study. 
The two futures considered for the Gloucester subregion are:

- baseline coal resource development (baseline): a future that includes all coal mines that were commercially producing as of December 2012;

- coal resource development pathway (CRDP): a future that includes all coal mines and coal seam gas fields that are in the baseline as well as those that are expected to begin commercial production after December 2012.

The difference in results between the CRDP and baseline is the change that is reported here. This change is due to the additional coal resource development - all coal mines and coal seam gas fields, including expansions of baseline operations, that were expected to begin commercial production after December 2012.

In the Gloucester subregion, the additional coal resource development (shown in Fig. 1) includes: (i) expansion of the Duralie open-cut mine, (ii) expansion of the Stratford open-cut mine, (iii) establishment of the Rocky Hill Mine, and (iv) establishment of Stage 1 of the Gloucester Gas Project.

The CRDP is the most likely future, based on consultation with coal and gas industry representatives, state agencies and the Australian Government. The CRDP was finalised for the Gloucester subregion based on information available in October 2015 (Dawes et al., 2018) to allow the hydrological numerical modelling to commence. In reality, developments in the CRDP may ultimately be implemented in different ways (e. g. changes to timing), or circumstances of coal resource developments may change (e. g. a proponent may withdraw for some reason). This reflects the dynamic nature of resource investment decision making, related to diverse economic, political or social factors. Consequently, the CRDP needs to be viewed as an indicative future that highlights potential changes for water resources and water-dependent assets that may need to be considered further in local analyses or via approval conditions required by regulators. Equally as important, the CRDP plays a role in identifying where changes will not occur, flagging where potential impacts to water resources and water-dependent assets are very unlikely.

Factors such as climate change and land use (such as agriculture) were held constant between the two futures. Although the future climate and/or land use may differ from those assumed here, the effect of this choice is likely small because the focus of this study is on reporting the difference in results between the baseline and CRDP.

This study focuses on those surface water and groundwater effects that may accumulate, either over extended time frames or as a result of multiple coal resource developments. These typically correspond to changes in surface water and groundwater that are sustained over long periods of time, generally decades, and which may create the potential for flow-on effects through the hydrological system. Many activities related to coal resource development may cause local or on-site changes to surface water or groundwater. These are not considered explicitly here because they are assumed to be adequately managed by site-based risk management and mitigation procedures and are unlikely to create potential cumulative impacts.

This study is designed to analyse the cumulative impacts of coal resource development at a regional scale, and not focus specifically on individual mines or coal seam gas operations. The baseline and CRDP futures for the Gloucester subregion include a suite of developments, the potential impacts of which may overlap to varying degrees in both time and space. 
Regional-scale models are used to predict the cumulative hydrological changes and potential impacts of those developments from multiple developments over time. The area of potential impact is expected to be more extensive and extend greater distances downstream of developments than what is predicted from site-scale, single-mine models. Results of the analysis reported here do not replace the need for the detailed site- or project-specific investigations that are currently required under existing Australian state and Commonwealth legislation. The hydrological modelling undertaken here is appropriate for assessing the potential impacts and risks to water resources and water-dependent assets at the 'whole-of-basin' scale, whereas the modelling undertaken by a mining proponent for an individual development as part of an environmental assessment, occurs at a much finer scale and makes use of local information. Therefore, results from these detailed mine-specific studies are expected to differ from those shown here. However, as a range of potential parameter values are considered here (see details below), it is expected that the range of possible outcomes predicted here will encompass the results from individual site-specific studies.

In this study, parameter uncertainty was considered as fully as possible when predicting hydrological outcomes (i. e. changes to surface water and groundwater). For example, groundwater models were run many thousands of times using a wide range of plausible input parameters for many of the critical hydraulic properties, such as the hydraulic conductivity and storage coefficients of all modelled hydrogeological layers. This differs from the traditional deterministic approach used more routinely for groundwater and surface water modelling and is driven by the risk analysis focus taken here.

While models are constrained to data, the density of reliable observation data is sparse, so results may not represent local conditions well. However, they do consistently represent the risk and uncertainty at all sites through probability distributions of possible hydrological changes, where the area, depth, timing and assumed pumping rates of each development largely determine the spatial variation, and lack of detail about the physical environment at any given point in the assessment area defines the uncertainty.

\section{Methods}

This section contains a description of the groundwater and surface water models that were constructed to assess the change in groundwater levels and surface water flows in the Gloucester subregion. A more complete description of the models is available in (Crosbie et al., 2016) and (Peeters et al., 2018) for groundwater, and (Viney, 2016) and (Zhang et al., 2018) for surface water, while an overview of the approach as a whole can be found in (Post, 2018).

The conceptual understanding of the Gloucester subregion is summarised in Fig. 2. The Gloucester Basin is considered to be a geologically closed basin with three main hydrogeological units:

- surface alluvium up to $15 \mathrm{~m}$ thick, a semi-confined to unconfined aquifer;

- shallow weathered and fractured rocks up to $150 \mathrm{~m}$ thick, a confined to semiconfined aquifer;

- interburden units alternating with coal seams to a maximum depth of about $2500 \mathrm{~m}$, only considered to be water-bearing strata. 



2018)

Fig. 2. Conceptual block diagram of the Gloucester subregion. Reproduced from Fig. 6 in (Post et al.,

The shallow weathered and fractured rock layer underlies the alluvium entirely, and outcrops extensively across the rest of the surface of the Gloucester subregion. Both the Avon and Karuah rivers are unregulated streams connected with local groundwater. The river system is mostly gaining, with baseflow estimated to be about one-tenth of total streamflow (Dawes et al., 2018). The alluvial aquifer only receives water from the river system during high flow and flood events.

The main causal pathways identified in (Dawes et al., 2018) for coal seam gas operations are aquifer depressurisation and inter-aquifer connectivity, while for open-cut mines the main causal pathways are disruption of natural surface water drainage and inter-aquifer connectivity, including pumping to dewater mines by lowering the watertable. Any water extraction in either the coal seams, interburden or the shallow weathered and fractured rocks has the potential to affect groundwater levels in the alluvium. A change in groundwater levels in the alluvium may affect the surface water-groundwater exchange flux and thus streamflow. Open-cut coal mines have a more direct impact on surface water flow as all rainfall within the mine footprint area is contained on site and no longer contributes to runoff. The role of faults and fractures which may increase or decrease inter-aquifer connectivity is highlighted as an important knowledge gap.

The objective of the numerical modelling undertaken in the Gloucester subregion is to probabilistically assess hydrological changes arising from coal resource development. The groundwater and surface water modelling predict changes in the hydrological characteristics of the system that potentially change due to coal resource development. 
Unlike typical applications of hydrological models, in this study, we do not apply an optimised calibrated model to determine likely impacts. Rather, we vary the parameters of each model over a 'likely range' as determined via expert opinion based on observed data. The range of results then provides us with the range of potential impacts. We do calibrate a surface water model in order to obtain optimal parameters to ensure that we are able to model the system adequately, but these parameters are not then used moving forward except to provide a reality check on the parameter range chosen.

The hydrological response variable reported for groundwater is maximum difference in drawdown for one realisation within an ensemble of groundwater modelling runs, obtained by choosing the maximum of the time series of differences between two futures. Remember that the difference in drawdown between CRDP and baseline is due to the additional coal resource development. For surface water, only change in total annual flow will be reported here. Changes in eight other hydrological response variables were derived and are reported in (Zhang et al., 2018), while decreases in the number of low-flow days are reported in (Post et al., 2020).

Simulating the change in hydrological response variables necessitates the development of an integrated surface water-groundwater model. Groundwater and surface water, however, operate at very different spatial and temporal scales. The surface water obviously is bound to the river channel and floodplain. Streamflow is very responsive to individual rainfall events, requiring at least a daily temporal resolution. The groundwater in the alluvium is bound to the alluvial sedimentary deposits, which form a strip along the rivers of about $15 \mathrm{~m}$ thick. Groundwater levels in the alluvium respond to changes in rainfall and river stage, albeit at a longer timescale than surface water. Capturing this dynamic in a numerical model necessitates at minimum a monthly resolution. The deeper hydrogeological units (i. e. the fracture rock layer, interburden and coal seams) are much more spatially extensive, both horizontally and vertically. The groundwater dynamics are very slow, with limited and delayed response to recharge events or flood events in the shallow weathered and fractured rock layer. To simulate this part of the groundwater system, a high temporal resolution is not required.

While fully coupled surface water-groundwater model codes are available, their use is not justified here due to the high data requirements for parameterisation. For this assessment, a pragmatic coupling of three models was developed, consisting of a regional groundwater model and an alluvial groundwater model to simulate the impact on the groundwater systems, and a rainfall-runoff model to simulate the impact on the surface water systems of the subregion (Fig. 3). The individual models have different spatial and temporal resolution which requires a set of customised processing steps to up or downscale model data to allow the models to be linked.

The regional groundwater model is an analytic element (AE) model, designed to simulate the change in drawdown associated with the groundwater bores in the Gloucester geological basin weathered zone, and to provide the change in groundwater level underneath the Avon and Karuah alluvium. The latter provides the lower boundary condition for the alluvial groundwater models. For both alluvial systems a MODFLOW model was developed to simulate the change in drawdown associated with the alluvium and the change in surface water-groundwater flux. This flux is taken into account in the Australian Water Resources Assessment landscape (AWRA-L) surface water model generated streamflow. The modelling of river management or routing of streamflow through the 


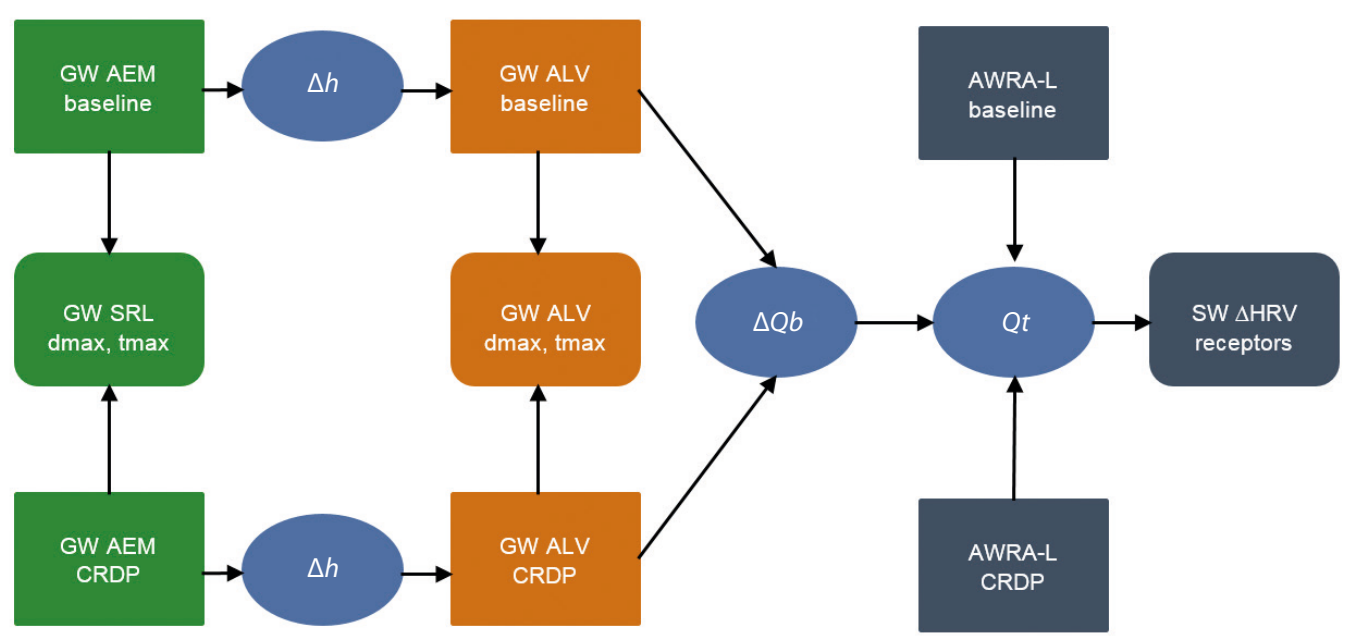

Fig. 3. Model sequence for the Gloucester subregion. GW AEM: regional analytic element groundwater model; GW ALV: alluvial MODFLOW groundwater model; AWRA-L: rainfall-runoff model; SRL: surface weathered and fractured rock layer; $\Delta h$ : change in groundwater level; $Q b$ : change in surface water groundwater interaction flux; Qt: total streamflow; HRV: change in hydrological response variable; CRDP: coal resource development pathway; SW: surface water. Reproduced from Fig. 3 in (Zhang et al., 2018)

river network with a river model is not necessary as the salient features of streamflow can be simulated solely with a rainfall-runoff model (see Viney, 2016).

Figure 3 shows the sequencing of the different models. In the GW AE baseline coal resource development (baseline) model, the impact of historical coal mines and coal mines commercially producing coal as of December 2012 are simulated. The GW AE CRDP model simulates the impact of the CRDP, which is the impact of the baseline coal resource developments as well as those that are expected to begin commercial production after December 2012. The difference in simulated drawdown between those two runs represents the impact of the additional coal resource development on the shallow weathered and fractured rock layer of the Gloucester geological basin.

The GW AE baseline model and GW AE CRDP model simulated impacts underneath the alluvium feed into the alluvial groundwater models for the Avon and Karuah rivers. The difference in simulated drawdown between these two models' runs represents the impact of the additional coal resource development on the Avon and Karuah alluvium. The GW ALV models for the Avon and Karuah rivers also simulate the time series of the change in surface water-groundwater exchange flux, $\Delta Q b(t)$, for the surface water catchments associated with receptor nodes in the AWRA-L model as:

$$
\Delta Q b(t)=Q b_{\text {baseline }}(t)-Q b_{C R D P}(t) .
$$

The AWRA-L baseline run therefore simulates streamflow incorporating the effect of existing and approved open-cut coal mines. The AWRA-L CRDP run simulates streamflow incorporating the effect of existing and approved open-cut coal mines plus the additional coal resource development. The total streamflow difference, $\Delta Q t(t)$ (due to additional coal resource development) is obtained as: 


$$
\Delta Q t(t)=Q t_{\text {baseline }}(t)-Q t_{C R D P}(t)-\Delta Q b(t)
$$

\section{Results}

\subsection{Groundwater}

The groundwater zone of potential hydrological change is defined as the area with a greater than $5 \%$ chance of exceeding $0.2 \mathrm{~m}$ of drawdown in the alluvium due to additional coal resource development. It means that $95 \%$ of groundwater model runs exceeded this level of drawdown. Groundwater impacts due to coal mines and CSG projects are regulated under state legislation and state regulatory and management frameworks. The $0.2 \mathrm{~m}$ drawdown threshold adopted here is consistent with the most conservative minimal impact threshold in the NSW Aquifer Interference Policy (DPI, 2012).

The groundwater zone of potential hydrological change for the Gloucester subregion is shown by the coloured area in Fig. 4, $c$ showing results at the $95^{\text {th }}$ percentile ( $5 \%$ chance of exceedance). It consists of an area of $88 \mathrm{~km}^{2}$ in the Gloucester river basin, and $12 \mathrm{~km}^{2}$ northwest of Stroud in the Karuah river basin. These two areas are around the proposed Rocky Hill Coal Project, Stratford expansion and the Gloucester Gas Project Stage 1 CSG field in the north, and the proposed Duralie expansion in the south.

Figure $4, a$ and $b$ show maximum predicted depth of drawdown due to the additional coal resource development for the $5^{\text {th }}$ and $50^{\text {th }}$ percentiles. These illustrate the variation in model predictions due to parameter uncertainty. Additional drawdown occurs in two areas, the first area in the Gloucester river basin, centred on the Rocky Hill mine; the second in the Karuah river basin around the Duralie mine. The area associated with the $5^{\text {th }}$ percentile $\left(19.7 \mathrm{~km}^{2}\right)$ can be interpreted as representing the extent of drawdown when the model parameters reflect lower pumping rates and/or lower hydraulic conductivities. Conversely, the area of drawdown associated with the $95^{\text {th }}$ percentile $\left(100 \mathrm{~km}^{2}\right)$ also includes the predictions based on higher pumping rates and relatively conductive geological layers. This is a general guide only as the influences of the different parameters can be complex and produce a range of drawdown responses. Groundwater drawdown predictions indicate that drawdowns of greater than $2 \mathrm{~m}$ are very likely (greater than $95 \%$ chance; $5^{\text {th }}$ percentile) due to the additional coal resource developments at Duralie and around Rocky Hill (Fig. 4, a). Generally, drawdowns exceeding $5 \mathrm{~m}$ due to the additional coal resource development are very unlikely, although the $95^{\text {th }}$ percentile map indicates the possibility of $>5 \mathrm{~m}$ drawdowns around the Rocky Hill development (Fig. 4, c).

\subsection{Surface water}

The potential hydrological changes in surface water are summarised by eight hydrological response variables as reported in (Zhang et al., 2018). These hydrological response variables were chosen to represent potential changes across the full flow regime: from low flows to high flows including two hydrological response variables to represent changes in flow volume and variability. The zone of potential hydrological change was defined based on exceeding a $5 \%$ change in any of these eight hydrological response variables. The surface water zone of potential hydrological change is shown in Fig. 5. It covers an area of $187 \mathrm{~km}^{2}$, with approximately $117 \mathrm{~km}^{2}$ in the Gloucester river basin and $70 \mathrm{~km}^{2}$ in the Karuah river basin. 


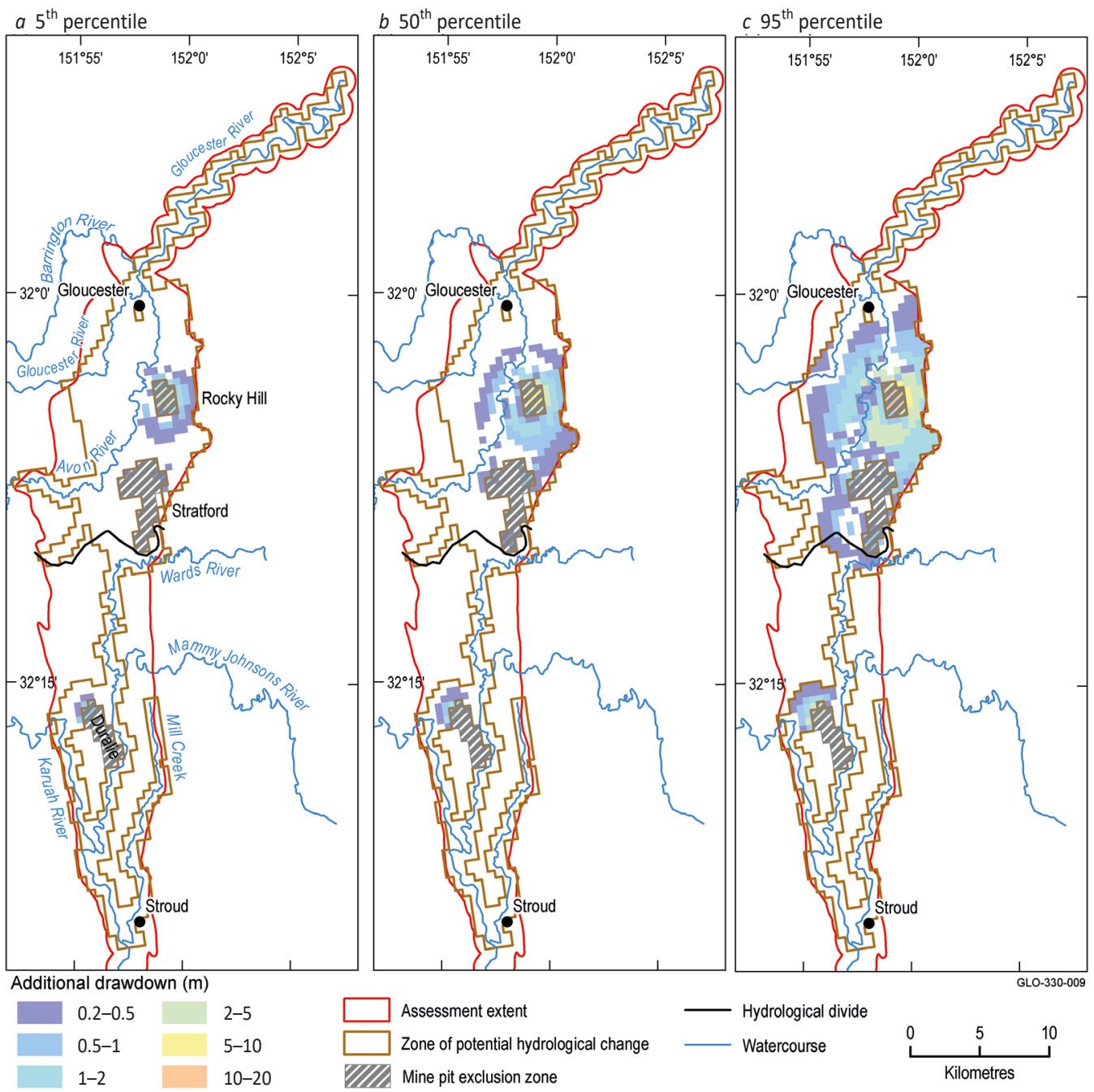

Fig. 4. Additional drawdown $(\mathrm{m})$ in the alluvium $\left(5^{\text {th }}, 50^{\text {th }}\right.$ and $95^{\text {th }}$ percentiles $)$. Additional drawdown is the maximum difference in drawdown between the coal resource development pathway (CRDP) and baseline model runs, representing the impact of additional coal resource development. Reproduced from Fig. 16 in (Post et al., 2018)

As can be seen from the reductions in annual flow shown in Fig. 6, the zone of potential hydrological change shown in Fig. 5 is very conservative. The decrease in annual flow due to additional coal resource development in the Gloucester subregion shows that the reductions in annual flow are identical at the $5^{\text {th }}, 50^{\text {th }}$, and $95^{\text {th }}$ percentiles. This is because the reductions in annual flow are driven primarily by the area of overland flow intercepted by the open-cut mine pits, which is not included in the uncertainty analysis. There are $1.7 \mathrm{~km}$ of stream with a little over $5 \%$ reduction on the stream downstream of the Stratford mine and an additional $24 \mathrm{~km}$ of stream with 1 to $5 \%$ reduction further downstream on the Avon River. 


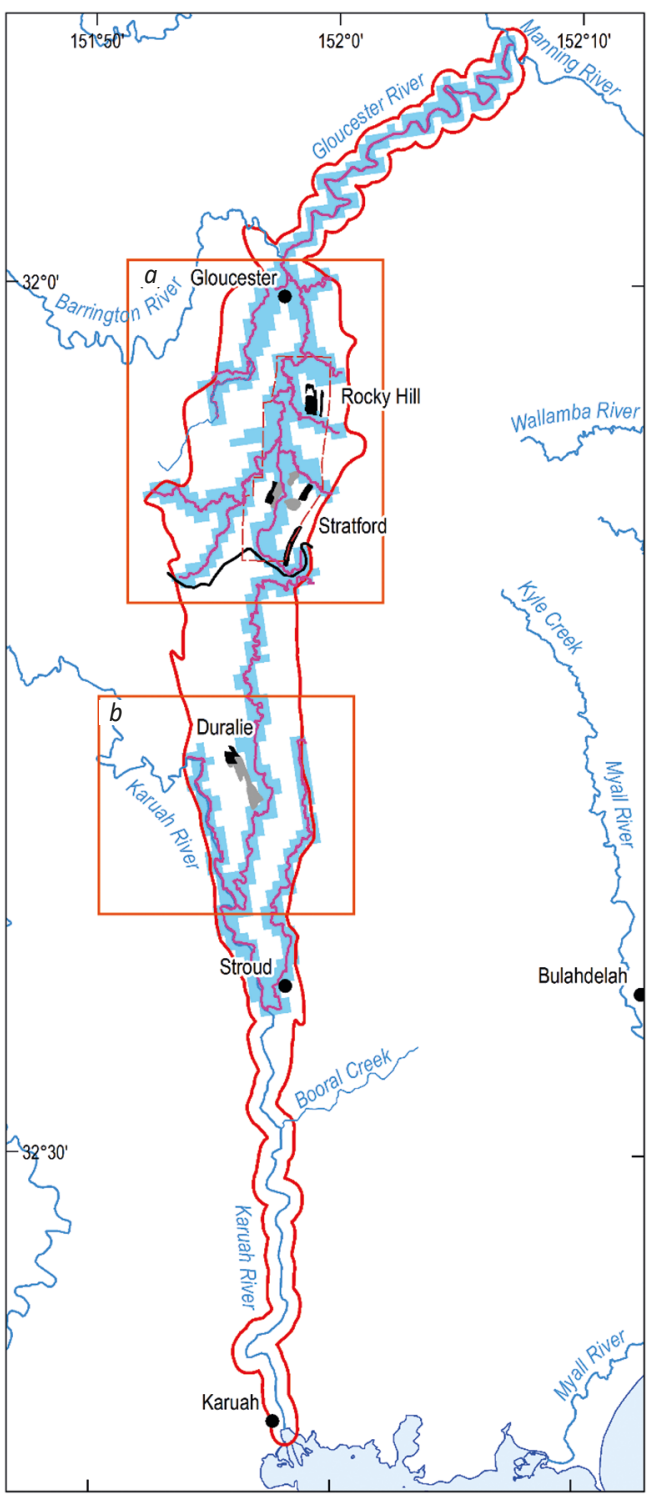

Surface water zone of potential hydrological change

Assessment extent

Hydrological divide

Potentially impacted reach

Watercourse

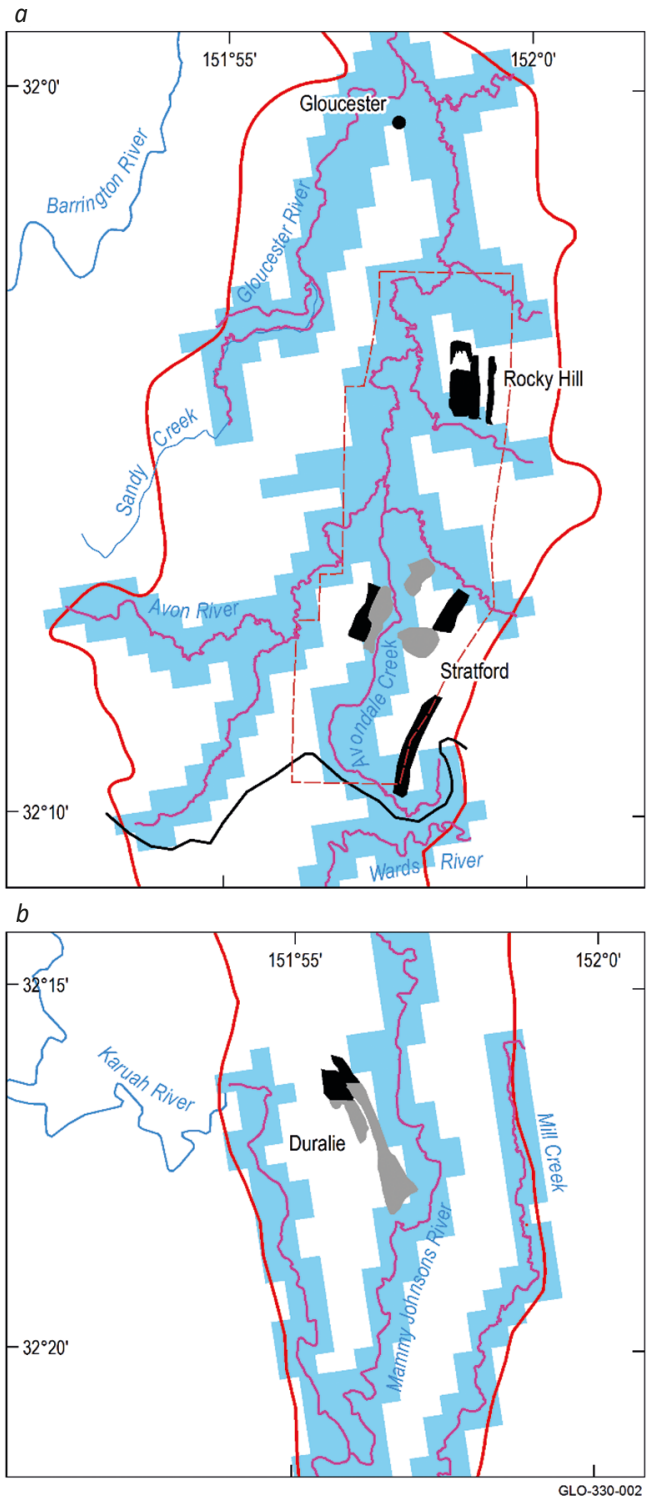

Mine operation

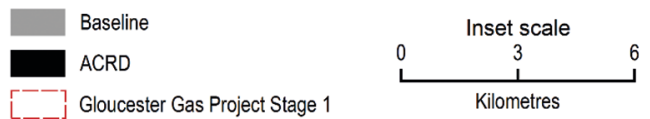

Fig. 5. Surface water zone of potential hydrological change. The surface water zone of potential hydrological change is the area where a change in any one of eight surface water hydrological response variables exceeds $5 \%$. Reproduced from Fig. 13 in (Post et al., 2018) 


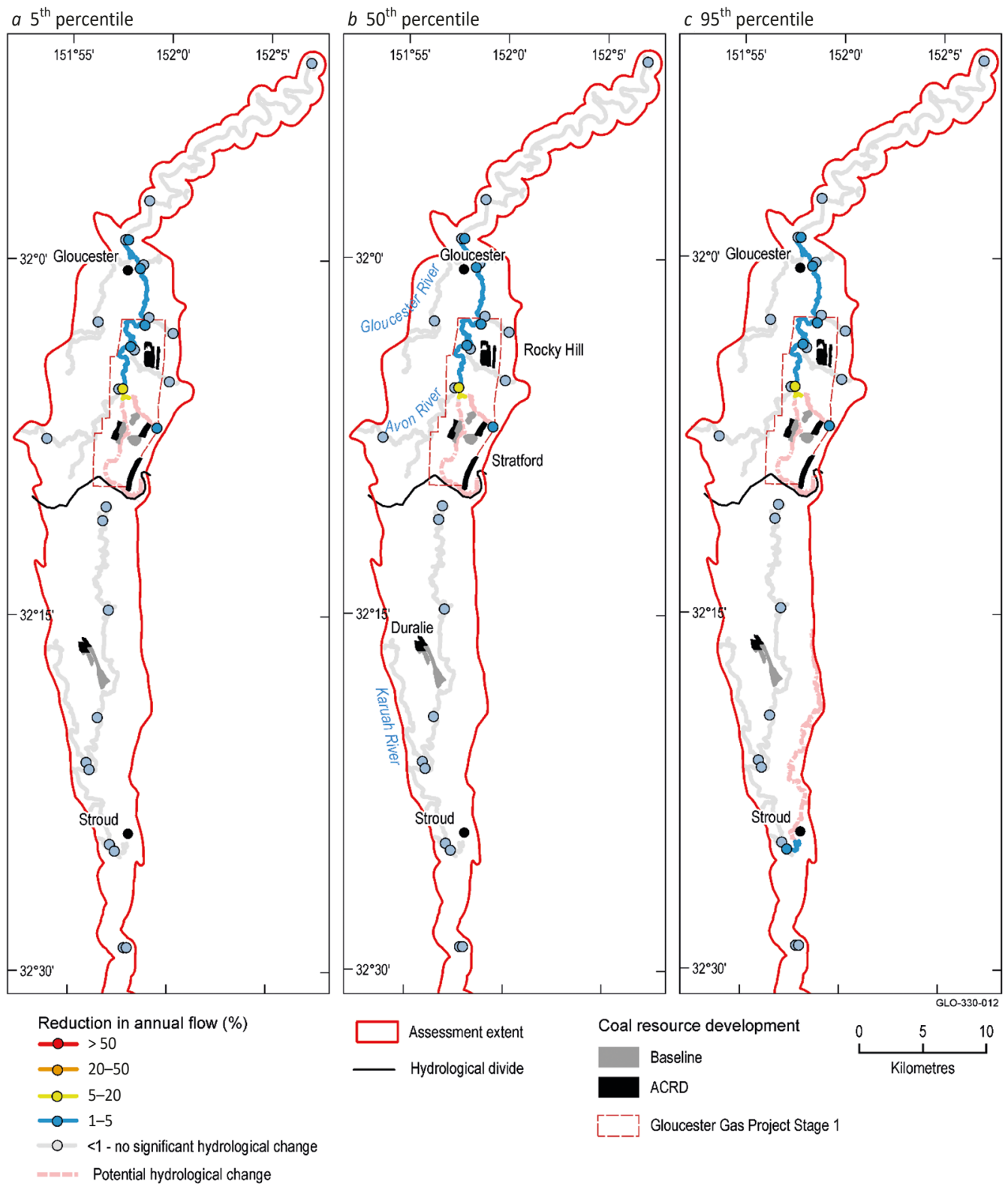

Fig. 6. Decrease in annual flow due to additional coal resource development (ACRD). Reproduced from Fig. 26 in (Post et al., 2018)

\section{Discussion}

\subsection{Groundwater}

Figure 4 shows that drawdown due to additional coal resource development can be small, even close to some of the coal mines. This is because Fig. 4 does not include drawdown that has already occurred due to coal mining that is in the baseline. The spatial dis- 


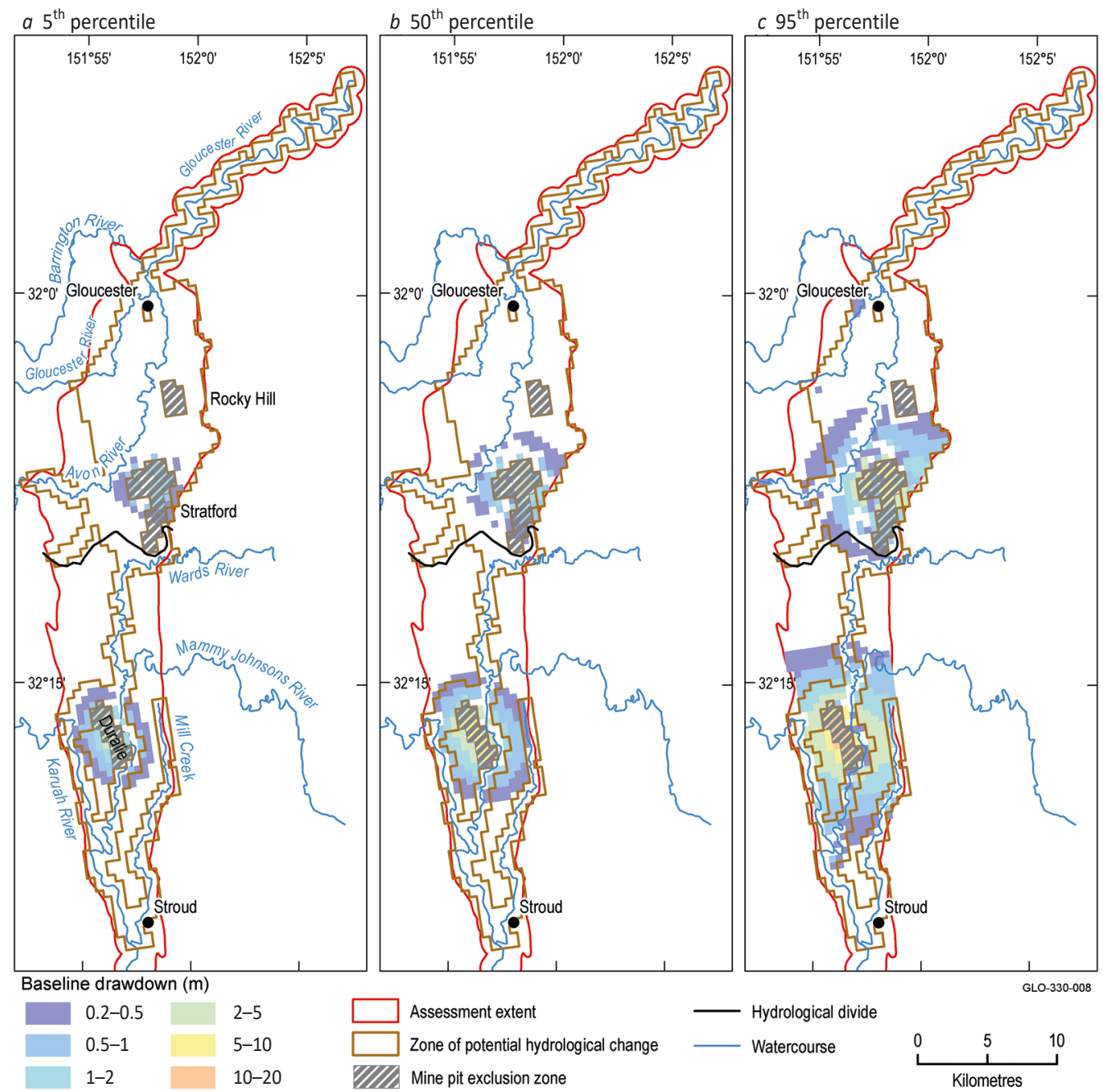

Fig. 7. Baseline drawdown $(\mathrm{m})$ in the alluvium $\left(5^{\text {th }}, 50^{\text {th }}\right.$ and $95^{\text {th }}$ percentiles $)$. Baseline drawdown is the maximum difference in drawdown under the baseline relative to no coal resource development. Reproduced from Fig. 17 in (Post et al., 2018)

tribution of drawdown under the baseline is shown in Fig. 7, providing a visual comparison to the potential groundwater drawdown due to additional coal resource development in Fig. 4. Under the baseline, the area with at least a $5 \%$ chance of drawdown greater than $0.2 \mathrm{~m}$ is about $140 \mathrm{~km}^{2}$. The areas of drawdown are associated with the baseline workings at the Duralie mine and the Stratford mine. The area of overlap with the groundwater zone is $53 \mathrm{~km}^{2}$ and represents the area where drawdowns due to baseline and additional coal resource developments potentially accumulate. Another $30 \mathrm{~km}^{2}$ overlaps with the surface water zone and defines the area where lagged groundwater drawdown responses from baseline developments could coincide with more instantaneous changes in streamflow due to the additional coal resource development. Thus, it is important to consider that additional drawdown may not occur, even due to additional developments, if the ground- 


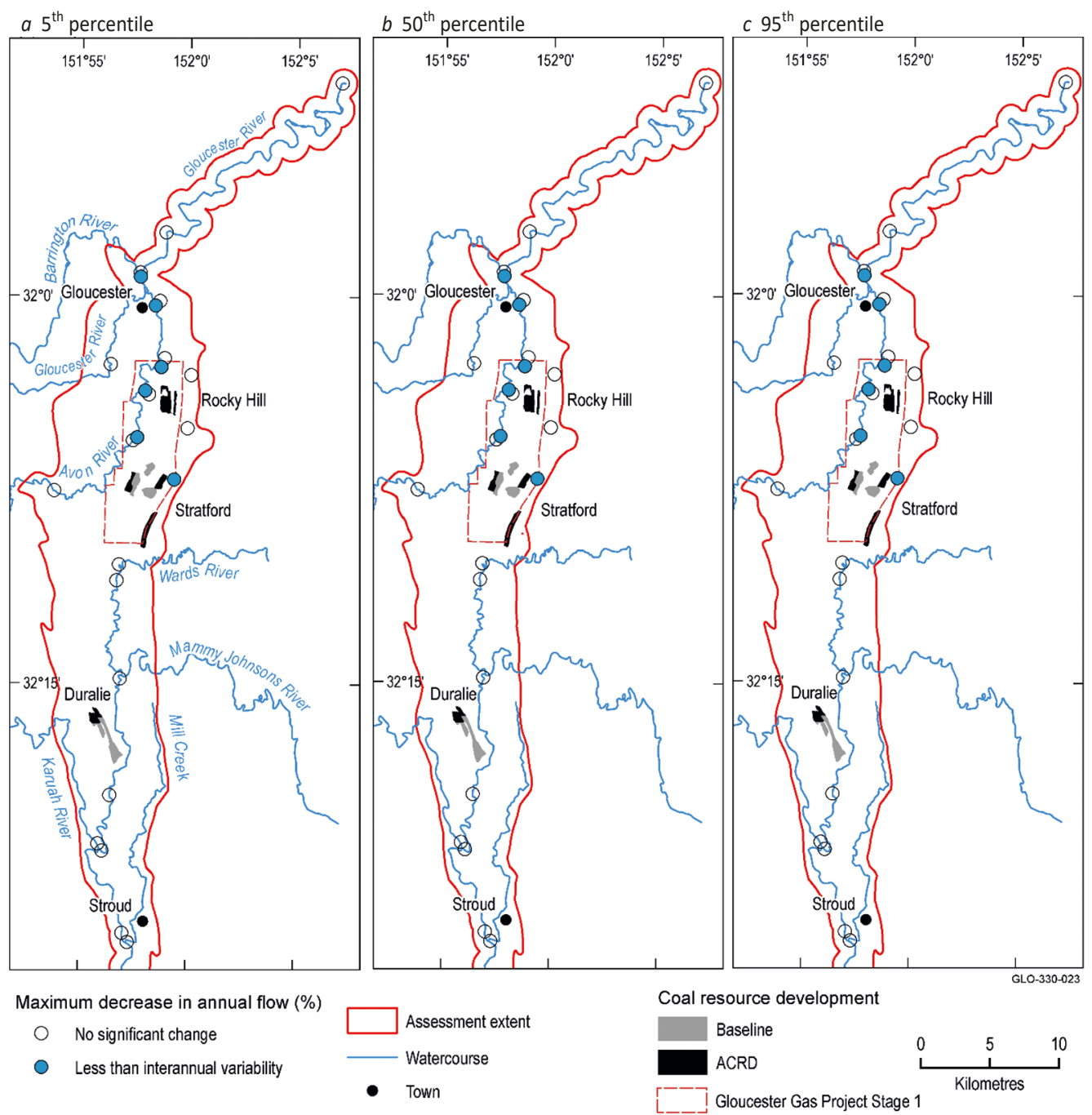

Fig. 8. Ratio of change in annual flow due to additional coal resource development (ACRD) to the interannual variability in annual flow. Reproduced from Fig. 28 in (Post et al., 2018)

water levels in that area have already been drawn down due to baseline coal resource developments.

\subsection{Surface water}

To understand the significance of the modelled decreases in annual flow, it is useful to look at them in the context of the interannual variability in annual flow due to climate. In other words, are the modelled decreases due to additional coal resource development within the natural range of variability of the longer-term flow regime, which would suggest the system is adapted to the range of possible decreases, or are they potentially moving the system outside the range of hydrological variability it experiences under the baseline? The maximum decrease in annual flow due to additional coal resource development relative to 
the interannual variability in annual flow under the baseline has been adopted to put some context around the modelled changes. This ratio is shown in Fig. 8.

It is important to be aware that the changes shown in Fig. 8 represent the maximum decrease in annual flow due to additional coal resource development in a single year relative to the interannual variability across 90 years under the baseline. Thus, it is not a comparison of distributions, but an assessment of whether the change due to additional coal resource development, in the year of maximum difference between the CRDP and the baseline, is within the range of natural variability. If the maximum change is small relative to the interannual variability due to climate, then the risk of impacts from the decrease in annual flow is likely to be low. If the maximum change is comparable to or greater than the interannual variability due to climate, then there is a greater risk of impact. However, since the change due to the additional coal resource development is additive, even a less than interannual variability' change is not free from risk, and the results of this analysis should be viewed as relative indicators of risk.

There are six model nodes where a reduction in annual flow is observed, and this change is less than the natural variability seen under the baseline (Fig. 8). The small reductions in annual flow due to the additional coal resource development are therefore unlikely to lead to significant impacts.

\section{Conclusion}

This study has investigated the potential impacts of additional coal resource development in the Gloucester subregion of Australia. The methodology described herein represents a generic approach that can be applied to determine the impacts of multiple resource developments within a region. While applied to Australia here, there should be no impediment to application in other countries. A range of possible parameter values for each of the groundwater and surface water models is required, and thus results will have greater uncertainty where these parameter values are not well measured. Nonetheless, the approach itself is sufficiently robust to handle such uncertainty, and the range of uncertainties can be reduced through field measurement of physical properties which define these model parameters. In Gloucester, the proposed additional coal resource development will have only a small impact on groundwater levels and annual streamflow. It should be noted however that these results are specific to this region and that other regions in Australia where this methodology has been applied show much larger hydrological changes due to coal resource development. Results for these other regions and more detailed results for other hydrological metrics in Gloucester can be found at Bioregional Assessment Program (2016).

\section{References}

Bioregional Assessment Program. Australian Government. (2016). [online] Available at: https://www.bioregionalassessments.gov.au/ [Accessed May 31, 2020].

Crosbie, R., Peeters, L. and Carey, H. (2016). Groundwater modelling. Submethodology M07 from the Bioregional Assessment Technical Programme. Department of the Environment and Energy, Bureau of Meteorology, CSIRO and Geoscience Australia, Australia. [online] Available at: http://data. bioregionalassessments.gov.au/submethodology/M07 [Accessed May 31, 2020].

Dawes, W.R., Macfarlane, C., McVicar, T.R., Wilkes, P.G., Rachakonda, P.K., Henderson, B. L., Ford, J.H., Hayes, K.R., O'Grady, A.P. and Marvanek, S.P. (2018). Conceptual modelling for the Gloucester 
subregion. Product 2.3 for the Gloucester subregion from the Northern Sydney Basin Bioregional Assessment. Department of the Environment and Energy, Bureau of Meteorology, CSIRO and Geoscience Australia, Australia. [online] Available at: http://data.bioregionalassessments.gov.au/product/NSB/ GLO/2.3 [Accessed May 31, 2020].

DPI. (2012). NSW Aquifer Interference Policy: NSW Government policy for the licensing and assessment of aquifer interference activities. NSW Department of Primary Industries, Office of Water. [online] Available at: http://www.water.nsw.gov.au/_data/assets/pdf_file/0004/549175/nsw_aquifer_interference_policy.pdf [Accessed May 31, 2020].

NSW Office of Water. (2013). An extract from the NSW Office of Water's Water Licensing System and Surface and Groundwater Approved Work locations. Extracted 20 November 2013. [online] Available at: https:// data.gov.au/data/dataset/deb952be-8b4a-40d2-ade0-2485b8d560c7 [Accessed May 31, 2020].

Peeters, L. J.M., Dawes, W.R., Rachakonda, P.R., Pagendam, D.E., Singh, R. M., Pickett, T. W., Frery, E., Marvanek, S.P. and McVicar, T.R. (2018). Groundwater numerical modelling for the Gloucester subregion. Product 2.6.2 for the Gloucester subregion from the Northern Sydney Basin Bioregional Assessment. Department of the Environment and Energy, Bureau of Meteorology, CSIRO and Geoscience Australia, Australia. [online] Available at: http://data.bioregionalassessments.gov.au/product/NSB/ GLO/2.6.2 [Accessed May 31, 2020].

Post, D.A. (2018). Bioregional Assessments: a robust methodology for carrying out cumulative impact assessments. In: Third Vinogradov Conference. Facets of Hydrology. [online] Saint-Petersburg: SaintPetersburg University Press, 834-838. Available at: http://publishing.intelgr.com/archive/hydrologyfacets.pdf [Accessed May 31, 2020].

Post, D. A., Henderson, B. L., MacFarlane, C., Herron, N., McVicar, T.R., Rachakonda, P. K., Hosack, G., Ickowicz, A., Hayes, K. R., Schmidt, R. K., Lewis, S., O’Grady, A., Barry, S., Brandon, C., Zhang, Y. Q., Peeters, L., Crosbie, R., Viney, N.R., Dambacher, J., Sudholz, C., Mount, R., Tetreault-Campbell, S., Gonzalez, D., Marvanek, S., Crawford, D. and Buettikofer, H. (2018). Impact and risk analysis for the Gloucester subregion. Product 3-4 for the Gloucester subregion from the Northern Sydney Basin Bioregional Assessment. [online] Department of the Environment and Energy, Bureau of Meteorology, CSIRO and Geoscience Australia. Available at: https://www.bioregionalassessments.gov.au/sites/ default/files/ba-nsb-glo-30-40-impactrisk-20180327a.pdf [Accessed May 31, 2020].

Post, D. A., Crosbie, R. S., Viney, N. R., Peeters, L. J. M., Zhang, Y., Herron, N., Janardhanan, S., Wilkins, A., Karim, F., Aryal, S., Pena-Arancibia, J., Lewis, S., Evans, T., Vaze, J., Chiew, F. H.S., Marvanek, S., Henderson, B., Schmidt, B. and Herr, A. (2020). Impacts of coal resource development in eastern Australia on groundwater and surface water. J.Hydrol., 591, 125281. https://doi.org/10.1016/j. jhydrol.2020.125281

Viney, N. (2016). Surface water modelling. Submethodology M06 from the Bioregional Assessment Technical Programme. Department of the Environment and Energy, Bureau of Meteorology, CSIRO and Geoscience Australia, Australia. [online] Available at: http://data.bioregionalassessments.gov.au/submethodology/ M06 [Accessed May 31, 2020].

Zhang, Y.Q., Viney, N.R., Peeters, L.J.M., Wang, B, Yang, A, Li, L.T., McVicar, T.R., Marvanek, S.P., Rachakonda, P.K., Shi, X.G., Pagendam, D.E. and Singh, R.M. (2018). Surface water numerical modelling for the Gloucester subregion. Product 2.6.1 for the Gloucester subregion from the Northern Sydney Basin Bioregional Assessment. Department of the Environment and Energy, Bureau of Meteorology, CSIRO and Geoscience Australia, Australia. [online] Available at: http://data.bioregionalassessments. gov.au/product/NSB/GLO/2.6.1 [Accessed May 31, 2020].

Received: June 11, 2020

Accepted: December 14, 2020

Contact information:

David A.Post — David.Post@csiro.au 


\title{
Оценка воздействия разработки угольных ресурсов на гидрологический режим (на примере Австралии)
}

\author{
Д. А. Пост \\ Государственное объединение научных и прикладных исследований, Отдел Земли и Воды, \\ Австралия, 2601, Канберра, GPO Вох 1700
}

Для цитирования: Post, D. A. (2021). Assessing the hydrological impacts of coal resource development: a case study from Australia. Вестник Санкт-Петербургского университета. Науки о Земле, 66 (1), 91-106. https://doi.org/10.21638/spbu07.2021.106

Целью исследования является оценка совокупного воздействия разработки угля на водные ресурсы в региональном масштабе на примере субрегиона Глостер в Новом Южном Уэльсе (NSW), Австралия. Основным результатом оценки, полученной в целях принятия решений заинтересованными сторонами (правительство, бизнес, общественные организации) в области регулирования, управления водными ресурсами и планирования, является определение территорий, где водные ресурсы вряд ли будут подвергнуты воздействию (с вероятностью менее $5 \%$ ), по сравнению с теми территориями, где водные ресурсы могут быть потенциально уязвимыми (вероятность как минимум $5 \%$ ). Оценка возможных воздействий проводилась на основе использования метода зонирования потенциальных изменений водных ресурсов. Такая зона определяется значением не менее $5 \%$ вероятности превышения рассчитанных пороговых значений показателей гидрологической реакции, включая истощение грунтовых вод и восьми других характеристик стока (здесь сообщается только о сокращении годового стока). Зона потенциальных гидрологических изменений в субрегионе Глостер охватывает площадь 250 км $^{2}(52 \%)$ и включает 242 км (70\%) русловой сети. Понижение уровня грунтовых вод в первом водоносном горизонте на более, чем 0.2 м из-за дополнительной разработки угольных ресурсов весьма вероятно (вероятность более $95 \%$ ) для площади $20 \mathrm{kм}^{2}$, но очень маловероятно (вероятность менее $5 \%$ ) что площадь терри-

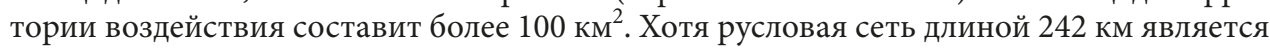
потенциально подверженной воздействию, изменения в речном стоке незначительны: вблизи угольных шахт слой годового стока уменьшается чуть более, чем на $5 \%$, а на основной части бассейна годового стока воды не превышает 1-5\%.

Ключевые слова: разработка угольных ресурсов, подземные воды, поверхностные воды, Австралия.

Статья поступила в редакцию 11 июня 2020 г. Статья рекомендована к печати 14 декабря 2020 г.

Контактная информация:

Дэвид A.Пост — David.Post@csiro.au 